\title{
Transcultural Orientalism
}

\author{
Re-writing the Orient from \\ Latin America and The Philippines
}

\section{Irene Villaescusa Illán}

Universiteit Utrecht, Netherlands

\section{Abstract}

This article investigates an alternative interpretation of Edward Said's concept of Orientalism both as theoretical approach and as a style of writing in three poems by Hispano-Filipino author Jesús Balmori (1887-1948). It argues that given the geopolitical location of the Philippines and its history of colonisation, the type of orientalism that Balmori's poems reveal can be understood as a form of transcultural writing that goes beyond the rigid binaries of East and West by simultaneously being located within both paradigms.

Filipino orientalism can be defined as transcultural (rather than peripheral, or transpacific, as Latin American orientalism(s) have been called) because it sees the orient through various other cultures while being in the Orient. Often the self and other that are created through orientalism are simultaneously the orientalising subject and the orientalised object. Transcultural orientalism serves to understand both the Eastern and Western elements of the Filipino cultural landscape through the optic of the various cultures that constitute it.

This article begins with a revision of the key ideas of Said's Orientalism followed by an analysis of the reaction towards those ideas by scholars and writers from Latin America. Specifically it focuses on Araceli Tinajero's study of the influence of orientalism in Latin American modern travel writing (2004) using examples by Guatemalan and Mexican authors Enrique Gómez Carrillo 
(1873-1927) and Juan José Tablada (1871-1945). As a counterpoint to the type of 'peripheral' or transpacific orientalism produced by these Latin American authors in their own (re)writings of the Orient, the analysis of Balmori's poems illustrates a transcultural perspective of orientalism achieved through three literary techniques which are often applied simultaneously: self-orientalization, mestizaje or mixing of oriental and occidental literary motives and consequently re-writing the idea the Orient and the Philippines in it.

\section{Keywords}

Orientalism, transculturation, travel writing, modernism, Hispano-Filipino literature 


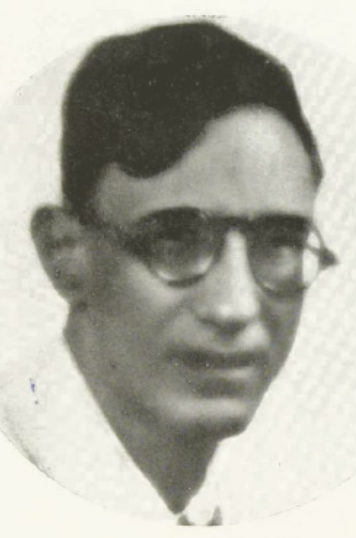

Lems Bahmon'

Fig. 1. Jesús Balmori in Mi casa de nipa, 5. Manila Gráfica edition, 1941

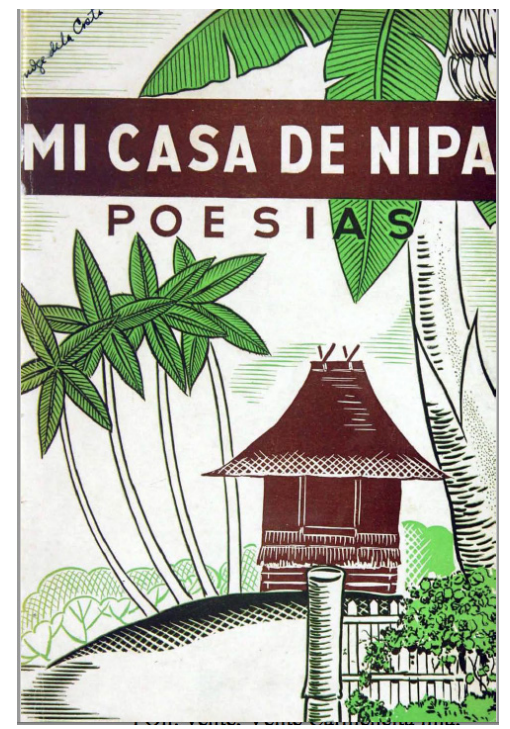

Fig. 2. Cover of the Manila Gráfica edition, 1941. Rizal Library, Ateneo de Manila University, Quezon City 


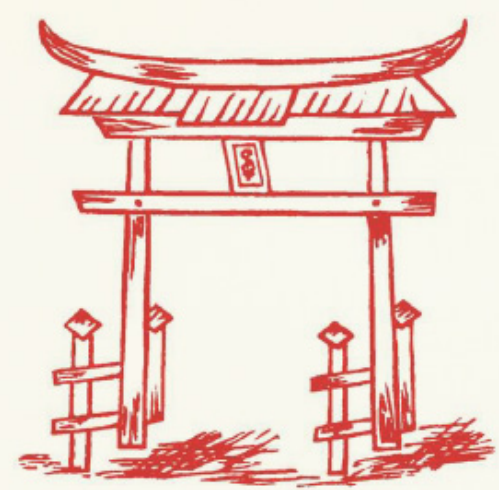

\section{A G UEISHA}

Fig. 3. La Gueisha's poem title and ilustration, 127, Mi casa de nipa, 1941. 


\section{Introduction}

Since Edward Said wrote Orientalism in 1978 his concept-explaining how Western knowledge about the East has been produced as an academic and popular discourse-continues to be discussed. New ideas have been added by Said himself ("Orientalism Reconsidered", 1985) as well as by other critics in various disciplines, helping to expand his theory towards new contexts. Araceli Tinajero's Orientalismo en el Modernismo Hispánico (2004) draws on Said's theory of orientalism in order to examine the vision and relationship with the Orient that prevails among Latin American modernists focusing on travel writers. With her study, Tinajero has revealed another route of cultural approximation between two "peripheral" contexts: Latin America and the Far East (el lejano oriente). She argues that the type of orientalism expressed in the travel diaries of modernist authors such as Juan José Tablada (Mexico, 1871-1945) and Enrique Gómez Carrillo (Guatemala, 1873-1927) seeks an encounter with the other in the spirit of cultural exchange and recognition rather than constructing the Orient as mythical place (populated by powerful Sultans, exotic dancers and barbaric peoples) to ultimately justify its subjugation in the form that Said points out in European and North American orientalism(s). Drawing from these two conceptualisations, Said's and Tinajero's, this article explores how Orientalism, a tool of knowledge production and as a style of writing takes shape in three poems of HispanoFilipino author, Jesús Balmori (1887-1948). This study argues that given the geopolitical location of the Philippines (in the Far East) and its history of colonisation, the type of orientalism that it revels can be understood as a form of transculturation. In other words, Filipino orientalism can be defined as transcultural (rather than peripheral, or transpacific, as Latin American orientalism(s) have been called) because it sees the orient through various other cultures while being in the orient. Often the self and other that are created through orientalism are simultaneously the orientalising subject and the orientalised object. Transcultural orientalism serves to understand both the Eastern and Western elements of the Filipino cultural landscape through the optic of the various cultures that constitute it. 
My analysis of Balmori’s poems "Rima Malaya” (1904), "Blasón” and "La Gueisha" (both published in 1941) shows that Filipino transcultural orientalism combines elements of other orientalism(s) in three ways: first, depicting an hegemonic discourse promoting assimilation to Western/ Spanish colonization; second, showing how literary modernism in the Philippines braids the orientalist styles from various Latin American and European traditions; and third, affirming its national identity based on the oriental and occidental aspects of Filipino transculturation.

\section{Orientalism and Cultural Encounters}

Said's Orientalism (1978) seeks to "understand the enormously systematic discipline by which European culture was able to manage-and even produce-the Orient politically, sociologically, militarily, scientifically and imaginatively during the post-Enlightenment period” (3). To Said, orientalism explains the process through which the Western world forged an image of the East-mostly the Middle East-as inferior, with the aim of domination. Said explains how the image of the other was constructed upon a discursive system establishing (still) prevailing binary oppositions such as Orient/Occident, Catholic/Muslim, science/religion, progress/underdevelopment, knowledge/labour and law/superstition. These oppositions defined what belongs to Eastern and the Western cultures, captained by the West with the consent of Oriental (and other) colonised peoples. The Gramscian idea of consent translates into the acceptance of the West as unquestionably superior and advanced-as something to look up to and forward to-both among the West and its others.

Said identifies orientalism in the fields of history, literature, art and politics, disclosing the elements that helped construct the image of the East as exotic, mythical, barbaric and anchored in the past. By elucidating Orientalism as a form of Foucauldian discourse, Said insists on the complexity of the phenomenon and offers a way to acknowledge its viral-like spread, affecting popular culture as well as academia. Providing an historical overview of how accounts of the Orient came into being, Said draws on exam- 
ples of the earliest colonial and imperial enterprises carried out by the West, which go back to the eighteenth-century Napoleonic invasion of Egypt.

Joan Torres-Pou's book Asia en la España del siglo XIX (2013) [Asia in Nineteenth-Century Spain] is one of the few works that focuses on cultural exchanges between Spain and Asia. Torres-Pou analyses the Spanish colonial discourse about the Philippines and the representation of the Orient by Spaniards in diplomatic reports, letters, journal articles, examples of travel writing and also literature, including Morsamor (1899), a travel novel by Juan Valera. Torres-Pou's research confirms the existence of an orientalist colonial discourse in accounts by Spanish intellectuals that justified Spanish imperialism based on a notion of racial inequality. Sinibaldo de Mas (1809-1869), who was the ambassador of Spain in Beijing in 1844 and consul general in Hong Kong in 1848, wrote a report entitled "Informe sobre el Estado de las Islas Filipinas" (1842) [Report on the State of the Philippine Islands] in which, in addition to presenting a scientific classification of what he had observed in the Philippines (populations, topography, agriculture, language, climate, flora and fauna), he repeatedly attempts to prove his conviction of "pertenecer a una raza superior" [belonging to a superior race] (qtd. In Torres-Pou 2013: 15). These testimonies from within Spanish colonialism/orientalism are symptomatic of the colonial institutionalisation of power over the Orient that Said denounces in Orientalism, and that was transmitted, as in the case of French and English imperialism, through the channels of intellectual, political, and travel writing.

Said's study identifies a generation of French and British pilgrim writers such Chateaubriand (1768-1849), Edward William Lane (1801-1876), who translated the 1001 Nights into English, and Thomas Edward Lawrence (18881935), better known as Lawrence of Arabia, as orientalists. However, he explains that their way of doing orientalism was different from Napoleon's, as they were driven by a philological and aesthetic aim rather than a political and colonial one:

French pilgrims did not seek a scientific so much as an exotic yet attractive reality. This is obviously true of the literary pilgrims, beginning with Chateaubriand, who found in the Orient a locale sympathetic to their 
private myths, obsessions, and requirements. Here we notice how all the pilgrims, but especially the French ones, exploit the Orient in their work so as in some urgent way to justify their existential vocation (Said 170).

Imperial travel writing, not only helped producing Western science (in opposition to Eastern tradition) but also, created an idea of the Orient that would become for European writers a source of inspiration that propelled their imagination and justified their writings (their "vocation"). It consequently lead to the creation of an orientalist discourse that was uncontested by reality, but presented as objective, and constricted by the western cultural lens of travel writing and literary inspiration.

Pratt, in Imperial Eyes: Travel Writing and Transculturation (1997), finds illustrative examples of Said's orientalist discourse in the travel accounts of British colonisers in Africa and Alexander Humboldt in Latin America. The most important points that she makes about orientalism and travel writing relevant here are two: first, that travel writing is at the origin of orientalist discourse because the voyage generates a series of "contact zones" where cultures meet and attempt to explain and understand each other; second, that travel responds to an desire to experience, directly, the otherwise abstract ideas about other peoples and other places. Pratt also develops an understanding of transculturation based on how the subjugated cultures of the contact zone engage with received epistemologies (that often orientalise them), which are often the only or dominant archives from which other knowledge may be created. This is what she calls transculturation, borrowing the term from Cuban scholar Fernando Ortiz. Ortiz's original definition of transculturation (1940) explains it as a three-way process that implies leaving things behind (deculturation), adopting new things (acculturation) and producing new meaning (neoculturation). The transculturation of literary forms, as thoroughly analysed by Ángel Rama in his canonical work Transculturación narrativa en América Latina (1982), helps to understand the way modernist poetry travelled from France, Nicaragua and Spain to the Philippines, and how it was transformed by each local writer that appropriated it. 
Thinking about orientalism from the East, or from other 'peripheries', raises questions about the terms in which people in these locations see, explain, create and imagine other cultures and themselves, and, consequently, about the productive role of orientalism as a tool of transculturation.

\section{Latin American Orientalism}

There are many studies that focus on how the Orient and Orientals are represented in Latin American literature focusing on the transpacific relationship between these two geographical locations. ${ }^{1}$ Araceli Tinajero's Orientalismo en el Modernismo Hispánico (2005) defines Latin American modernist writing as a type of peripheral orientalism because it emerges from what is considered, from a European perspective, a periphery. Tinajero explains this south to south relationship using the concepts of centre and periphery. In doing so she affirms that Latin American orientalism goes beyond the centrality of European orientalism establishing a dialectic relationship between two geographical and epistemological peripheries:

Para el modernista [latinoamericano] el acto de orientalizar no significaba encontrar una respuesta opuesta a los conceptos éticos, morales o estéticos de la sociedad europea. Tampoco se trataba de dar una respuesta al orientalismo europeo finisecular ni mucho menos de imitar a ciegas su producción literaria. Esto lo enfatizó Aníbal González al proponer que los modernistas sabían exactamente lo que hacían cuando en un mismo texto combinaban referencias al Lejano Oriente con aquéllas de las culturas indígenas y al mismo tiempo citaban autores europeos (54). En ese sentido los miembros del movimiento "dialogan" con orientalistas europeos, pero eso no quiere decir que la razón por la cual los primeros se aproximan al Oriente esté basada en ofrecer exclusivamente antagonismos a la visión europea sobre esa parte del mundo (Tinajero 19 , emphasis in text). ${ }^{2}$

As this quote suggests, Latin American modernist orientalists knew of European orientalism but did not approach the Orient solely to refute this European discourse. Instead, they incorporated both the European and 'their own' view of the Orient in the form of a transcultural style based on pastiche, cultural exchange and historical recognition. The dialogue between oriental- 
ism(s) is therefore not only peripheral, it does not skip the European centre, but re-writes it making orientalism in Hispanic modernism global, or as I suggest, transcultural.

Latin American orientalists such as Ruben Darío, Juan José Tablada and Enrique Gómez Carrillo found in the el lejano oriente, an appealing space which they could use to re-signify European orientalism, including the particular type of Spanish orientalism derived from the turbulent history between Christianity and Islam - embedded in the figure of the moor, 'el moro'-that Latin Americans (and Filipinos) received as part of a cultural and linguistic imaginary. Latin American orientalists saw in Asian peoples, a community with which they could forge an connection outside colonialism, at times, through the foundational myth that Amerindians had come from the East (Camayd-Freixas 1). Orientalism as practiced by Latin American modernist writers is therefore first defined by the distance of both Latin America and Asia from the European centre, and second by a desire to connect with an 'other' perceived as equal. Latin American modernist travel writers declare themselves different from the French and English modernists in writing in a "spirit of veneration and respect for the Orient" (Gómez Carrillo 3). Tablada kept a diary during his trips to Japan in the 1900s. In the following excerpt, he comments on the way he perceives texts from the French tradition:

Concluyo de leer por segunda vez la Madame Chrysanthème de Loti y a la vez que me encanta los prestigios del delicioso escritor me exaspera la frivolidad de sus juicios, la perfecta incomprensión del verdadero tipo japonés. (qtd. in Tinajero 10$)^{3}$

Tablada is enchanted with Loti's s delightful writing while at the same time critical of him for remaining superficial, frivolous and uncomprehending of the "true Japanese." The following fragment, published in the Mexican newspaper La Patria in 1900, illustrates the mentality and role of these Latin American travel writers as orientalists:

José Juan Tablada parte mañana para el Japón. El poeta realiza su sueño de toda una juventud... ¡Ve, artista! ¡Ve, escogido!... Estudia y fructifica, y que 
tu labor acrisolada en la palpación de la más sugestiva de las artes plásticas, porque es soberanamente original, sea simiente fecunda en nuestra tierra... Cuando contemples arrobado flotar en un mar de oro el témpano de nieve del Fusiyama , sueña en el lejano y augusto Citlaltépetl (qtd. in Tinajero 32). ${ }^{4}$

The comparison made here between a Japanese and a Mexican volcano establishes a new route from the Far West to the Far East that will serve as fertile soil for a new form of cultural expression. But the directionality of this new form of cultural expression is clear from the newspaper fragment: it is not so much about them (the Japanese), as it is about what we (Mexicans) can learn from them. In doing so, Tablada, the traveller/writer is the subject that sees Japan as the object of knowledge assuming thus the position of the seer, the orientalist. This type of orientalist perspective does not stablish a cultural hierarchy or aims at dominating the other perceived as inferior but find on that other a source of self-knowledge.

In Gómez Carrillo's commentaries on his trip to Asia, published as De Marsella a Tokyo: Sensaciones de Egipto, la India, la China y el Japón (1906), there is an illustrative example of self-knowledge and cultural identification between the Guatemalan with a Chinese traveller occur. The traveller/writer is on board to Egypt when he encounteres a Chinese man whom he describes as "no vulgar, un mercader, un banquero, no, ni siquiera un diplomático, sino un sabio chino, un chino doctoral" [not vulgar, not a banker, not even a diplomat, but a wise Chinese man, a doctoral Chinese!] (Gómez Carrillo 25). This man spoke various European languages, including Spanish, and was writing a book demonstrating that America had not been 'discovered' by Christopher Columbus but by a Chinese admiral. Interested by this new version of history, Gómez Carrillo continues conversing with him and eventually informs his interlocutor that : he has discovered that the Chinese and the Mexican calendars are identical, and so are most of the religious and philosophical beliefs in ancient China and pre-Columbian Mexico:

la transmigración de las almas, las atribuciones de las divinidades domésticas, los amuletos, la creencia en que el dragón devora al sol en sus eclipses, las 
reglas monásticas, que son idénticas en la China antigua y en el antiguo Méjico (Gómez Carrillo 27). ${ }^{5}$

Once in Egypt, Gómez Carrillo talks to an Egyptian judge and writes the following:

[El Viejo Egipto] no estaba muerto. Los musulmanes y los ingleses han podido dominarlo pero no transformarlo. Un soplo nacional fuerte, bastaría para hacer desaparecer los turbantes y los cascos coloniales (Gómez Carrillo $36) \cdot{ }^{6}$

Gómez Carrillo chooses to incorporate in his travelogue the voices of Asian people, especially the well-educated, whose voices subvert the master narratives of colonialism. In the quote above, identification with "the old Egypt" (pre-colonial) $^{7}$ occurs through a perceived shared history with another orientalised/colonised people to whom Carrillo projects the possibilities of action of (post-colonial) nationalisms that he has observed in the discourses for independence in Latin America.

These two fragments from Gómez Carrillo's travelogue give two examples of cultural identification: understanding Mexican pre-Columbian cosmology facilitates comprehending the teleology behind the Chinese horoscope, Mexico and China share cultural and religious artifacts, and Latin America and Egypt can survive their specific histories of colonisation in similar if not identical ways. It is possible to conclude that Mexican and Guatemalan orientalism as depicted by Tablada and Gómez Carrillo dismisses the cultural hegemony that Said's identifies in European orientalism as a colonial discourse. Even though these travel accounts continue to be based on a search for identity and self-definition through the other, they seek for an evaluation of self and other on rather equal terms: Japan and China are perceived not as an 'inferior' (lagging behind modernity) to Mexico and Guatemala (or the whole of Latin America) but as a cultural counterparts. 


\section{Transcultural Orientalism in Balmori's Poems}

Jesús Balmori was born in 1886 in Ermita, Manila, he worked as a lawyer for a while but dedicated most of his working life to journalism and writing, at a time when Spanish was at its peak as the medium of the Filipino press. Balmori was one of the most active contributors to Spanish newspapers such as La Vanguardia, El Debate and Voz de Manila, as well as the weekly Revista Filipina, in which most of the Spanish literary production of the Philippines-poems, stories, essays and novels-was published. Under the pseudonym "Batikuling" Balmori published numerous pieces of satirical poetry criticising the government and fast-changing Manilean society. Many of the columns he wrote were compiled in a book entitled El libro de mis vidas manileñas, published in 1928, which Donoso describes as a "truly delicious book about the socio-political life of his time" (2012: XVI).

Besides his work as a journalist, Balmori was also known as a muchlauded poet; he was a competitor and admirer of Manuel Bernabé (18901960), another key author in Hispanic Philippine literature. Together, they wrote Balagtasán, a type of poetry duel for which they won the Zóbel Prize in 1926. Balmori's early novels, Bancarrota de almas (1910) [Bankrupt souls] and Se deshojó la flor (1915) [Leafless flower], criticize the influence of American culture on Filipino society, specifically on women. His last novel, Los pájaros de fuego. Novela filipina de la guerra [Birds of Fire, A Filipino War Novel], written in 1945, is considered his best work in prose.

Balmori visited Mexico in 1931 with the aim of promoting Filipino literature in Spanish. He organized various cultural events among which were readings of his own poems (Park, 2018). He was certainly familiar with the works of Tablada but was most influenced by Ruben Darío (1867-1916) and crucially, as my analysis of Balmori's "Blasón" demonstrates, by Peruvian author José Santos Chocano (1875-1934). In fact, Darío, Santos-Chocano and Balmori have a poem entitled "Blasón" dating respectively from 1896 (in Prosas profanas), 1906 (in Alma América) and 1941(in Mi casa de nipa). I will compare the late two a few lines below. The modern rhetoric that exoticizes the orient travelled globally from France to Latin America and on a transpacific route to the Philippines, with orientalism undergoing a glocal process 
of transculturation. Balmori's orientalism does not originate in narratives of travel but draws from the particular orient in which the Philippines are located.

To delineate the characteristics of Filipino transcultural orientalism, I focus on three of Balmori's poems: "Rima Malaya" [Malayan Rhyme], from a collection of poetry Balmori wrote when he was 17 years old entitled Rimas Malayas [Malayan Rhymes] (1904), and "Blasón" [Code of arms] and "La Gueisha" [The Geisha], both from Mi casa de Nipa [My house of Nipa], published in 1941. My analysis does not follow the chronological order of the publication of the poems but my argument of how transcultural orientalism adopts various orientalist discourses and shows different literary techniques from the more 'imitative' (showing what Ortiz would have called acculturation, assimilation to other literary forms) to the more experimental (creating new literary forms). By considering "Blasón” an imitation of something else I am specifically referring to Santos Chocano's “Blasón” published in 1906. Donoso (2012) affirms that Santos Chocano inspired Jesús Blamori's own re-writing of Filipino mestizaje to be used as an affirmation of national identity and indeed the similarities are remarkable.

In (his) "Blasón” Balmori attaches Filipino identity to historical, racial and religious elements in a way that reiterates an orientalist colonial discourse:

Soy un bardo indohispano. En mi pecho cristiano mi corazón es vaso donde mezclada está la sangre de Legazpi, el capitán hispano, con la sangre tagala de la hija del Rajah

Con el talón hundido en olas y en espumas esperé sobre el mar el galeón español y España, al encontrarme, besó las áureas plumas que en mi frente temblaban como rayos de sol.

Era hermosa, era buena, era plena de amores; puse a sus pies mis lanzas, mis espigas, mis flores; le di mi corazón salvaje y oriental; 
Y desde entonces va en mi pecho desnudo sirviéndome de férreo y de glorioso escudo con su idioma divino y su sangre inmortal ${ }^{9}(27-28)$

"Blason" mobilises several identity attachments. The narrator describes himself as an Indo-Hispanic poet, ${ }^{10}$ a mix between the Spanish coloniser Legazpi (the leader of the first Spaniards to arrive in Manila) and the Tagalog daughter of a 'Rajah. ${ }^{11}$ The poem includes Filipino cultural and racial heritage by recognising elements of pre-Hispanic cultures (Islamic and Tagalog), but privileges the Hispanic elements, as indicated by the contrast between the reference to a named historical Spaniard (Legazpi) and to a nameless Tagala, daughter of an unidentified Muslim king ("rajah"). A feminised Spain described as "hermosa," "buena" and "plena de amores" [beautiful, good and loving] arrives to the coast of the Philippines, where an expectant 'native' surrenders to her, putting down his weapons (spears, thorns) and, most remarkably, offering the newcomer his "salvaje corazón oriental" [wild Oriental heart]. The wild heart may refer to a heart wild with love or to the wildness of the 'native' heart, thus orientalising him through a colonial discourse that justified the arrival of the foreigner to fulfil its 'mission' of civilizing the 'wild.' Either way, the voluntary act of surrendering the narrator's weapons and heart to (a mother?) Spain dismisses the violence of the first colonial encounter and suggests that the speaker's attachment to Spanish colonialism is a positive one. This suggestion is reinforced by the reference to the way the narrator now carries Spain, its "divine language" and "immortal blood" like a shield.

Santos Chocano's poem opens with the following sentence: "Soy el cantor de América / autóctono y salvaje”, reiterating the idea of the American side of the hybrid identity carried by the poem's narrator being (also) wild. Both poems talk about racial mixing of Spanish blood and respectively a Tagalog or an Incan heart: "la sangre es española/ e incaico es el latido". However, Santos Chocano's poem speaks of identity as identification meanwhile Balmori expresses the poet's identity as being, a permanent condition, rather than an alternating temporary feeling: 
cuando me siento inca/le rindo vasallaje al sol que me da el cetro de su poder real; cuando me siento hispano y evoco el coloniaje parecen mis estrofas/trompetas de cristal

Returning to Balmori's verses, the retelling of Filipino history proposed in his poem contrasts greatly with how official history relates the arrival of early colonisers from Spain: Ferdinand Magellans (1480-1521) in Cebu and Manuel Lopez de Legazpi (1503-1572) in Manila. Having survived the majority of men that participated in the first expedition to circumnavigate the globe under the command of Sebastian El Cano, Magellan arrived on the island of Cebu in 1521. Shortly after, he was killed in the battle of Mactan against the Malayan chief Lapu-Lapu, who had refused to be converted to Christianity. Later expeditions arrived to Manila, where Rajah Sulayman (1558-1575) ruled. Suleyman resisted subjugation to Legazpi and waged a war against the Spanish. In the Philippines, both Lapu-Lapu and Sulayman are iconic figures of resistance against the Spanish.

The description of the first colonial encounter in Balmori's poem dismisses its violence, praising instead what it has produced: a new-born Filipino who has inherited Spanish "immortal blood" and the "divine language" in which this poem is written. The opening line of "Blasón" recognises the hybrid identity of the Filipino poet as Indo-Hispanic but what follows sees the Indo surrendering to Spain and glorifying only the Spanish part of his heritage. The indigenous man is reduced to the recipient of an 'Oriental heart' that is willingly offered to the coloniser. Another explanation for the glorification of Spain and Spanish in this poem could be that, at the time it was published, in 1941, over forty years had passed since the US became the new coloniser. Most Hispano-Filipino writers resisted the Americanisation of the Philippines as another form of colonialism and attached themselves to their Hispanic heritage, especially the language, as a form of resistance. This turn to privileging one coloniser over the other simply adds one more argument to understand "Blasón" as an example of transcultural orientalism 
repeating Said's idea of cultural hegemony in which the colonised Tagalog (via the poetic voice) become (tenderly) Hispanised by the figure of Spain.

"Rima Malaya", a poem contained in one of Balmori's earliest poetry collections entitled Rimas Malayas (1904), describes a romantic scene; the male speaker of the poem tells how he secretly enters the chamber of his beloved and persuades her to run away with him:

Era la noche tropical de oriente

Alumbrada por una luna soñolienta

Brillaban fugaces mil relámpagos

Y el trueno retumbaba con violencia

Mudo el jardín, las aves dormitaban

En sus nidos de plumas y hojas

Y las auras calladas susurraban

Girando entre los lirios y las rosas

Con pie dudoso y vacilantes manos

Trepé la verja de dorados hilos

El céfiro traíame en sus alas

El trémulo rumor de sus suspiros. ${ }^{12}$ (37)

The opening stanza locates the action of this poem in an abstract Oriental space referred to as "la noche tropical de oriente" [the tropical night of the orient]. Although it is possible to infer that the narrator is referring to the Philippines from the poem's title, it is not until its last stanzas (11 and 12) that local Filipino elements appear:

Es decir, sí, me iré pero contigo

Allá al bosque oriental de verdes ramas

Donde las mayas rimen nuestro idilio

Donde te aguarda un lecho de sampagas. (38)

[...]

i Oh! vente, Vente Carmencita mía,

Si no sabes amar, yo allí á tus plantas

Cantándote el vals de los Kundimans

Coronaré tu frente de champakas. ${ }^{13}$ (39) 
In the eleventh stanza, the narrator suggests running away to an 'Oriental forest' populated by "mayas," a general term for small birds such as sparrows original from the Philippines, where the lovers may rest on a bed of "sampagas," the Filipino national flower. The narrator says that he will entertain his lover by singing the vals of the Kundiman, a traditional Filipino love song, and crowning her with "champakas," a type of magnolia from South East Asia. Significantly, the tropical forest to which the lovers want to run away (although certainly idealized) is a landscape of the Philippines. In opposition, the image of the garden that opens the poem is constructed with non-indigenous elements and metaphors: lilies, roses, and the metaphor of the Zephyr, the God of the West wind in Greek mythology.

The central part of the poem describes how the narrator/lover climbs up to a balcony from which he walks towards the room of his beloved. The poem does not identify her home as a palace, a castle, a tower or a Nipa house, but the narrator does explain that to get to the room where his ("white") beloved Carmencita was peacefully sleeping he had to cross "one thousand rooms", surrounded by "tinieblas" and "sombras," darkness and shadows (38). This section invokes elements of the western romantic tradition, such as the garden, the white, princess-like character in her secluded bedroom and the gothic-like description of the dark dwelling. The combination of themes (lovers eloping), settings (the garden versus the tropical forest), characters (a white princess-like figure, flowers, songs and dense nature) and the lyrical use of the Spanish language make this poem an example of a transcultural modernist/romantic poetry where the Filipino landscape is orientalised but the indigenous elements are not subsumed to the European ones, as in "Blasón," but presented at the same level: they are all part of an idealised fantasy world. More importantly, the indigenous forest is preferred over the western garden, where the lovers flee to. The poem ends with a distinctly transcultural image: the "white" princess and the presumably indigenous narrator united in the forest. She, the foreigner/coloniser is brought into the world of the indigenous/colonised. In contrast with "Blasón," in which the Indo-Hispanic poet/narrator begins by bringing up his transcultural heritage only to dissolve it into the glorification of Spain, "Rima Malaya" shows 
the two cultures coming together while remaining distinct. This emphasises dynamic transculturation leading to neoculturation-over cultural erasure (deculturation) and cultural appropriation (acculturation).

This poem is a clear example of Filipino modernism, written in the first decade of the twentieth century, thus showing its contemporaneity to the Latin American orientalist modernism. The practice of modernism in the Philippines was criticised, as it was in Latin America, by contemporary critics who considered the dwelling on romantic words an imitation of foreign (French) poetry and therefore an anti-nationalist gesture. For some, this type of baroque poetry betrayed the local in favour of the foreign, demonstrating assimilationist colonial practices. The practice of indigenismo in Latin America (by key authors such as the peruvian José María Arguedas 1911-1969) appeared as a reaction to this. W. E. Retana, one of the few Spanish literary critics who wrote about the Philippines in the early twentieth century, points out that the abuse of lilies and violets by some Filipino poets was regrettable since these flowers are not native to the Philippines: "it is as if the Filipinos find the Flora of their country unworthy" (Retana qtd. in Donoso 6). Retana's critique does not, however, apply to this poem, where the indigenous Filipino landscape is chosen over the western garden, but also transculturated through the coming together of the lovers in it. Moreover, Balmori's literary indigenismo, displayed in the incorporation of vernacular Malay words (sampaguitas, champakas, mayas, kundiman) into a poem written in Spanish, produces a very specific transcultural Filipino identity. In "Blason", it is the native who becomes Spanish; here, it is the princess-like figure that is, to an extent, indigenised by the narrator.

Retana, however, insists on highlighting the foreign aspects instead of the local ones in Hispano-Filipino works. In the following acerbic quote, he explicitly attacks the superficial and "excessive modernism" of the young Balmori:

Á Jesús Balmori, uno de los poetas más jóvenes, le incluyo entre los que más llegarían á valer; pero el ataque de modernismo fulminante que padece no sé si le dejará seguir viviendo. Balmori no ha salido de su patria, y, sin embargo, vive mentalmente en París, en el París misterioso, trágicamente bohemio, 
del Barrio Latino... Balmori quiere a toda costa ser un parisino enfermo, y enfermo se ha puesto, por pura espiritualidad, porque no concibe ser poeta si no es muriéndose de tristeza, de tristeza parisina. [...] He cargado la mano de la censura en Balmori, porque Balmori tiene el alma de poeta, vale, y se está tirando a matar á consecuencia de haberse creado a sí mismo un ambiente falso y antifilipino; y la crítica justa debe pedirle cuentas de tan sensible aberración. En Balmori luchan en espíritu, que es el de un buen patriota, y el cerebro, que es el de un parisiense de doublé: y como pone su voluntad al servicio del cerebro, resulta que muchas de sus composiciones son... un verdadero dolor. ${ }^{14}$ (qtd. in Donoso 17-18)

Retana's critique derives from his conviction that literature in the Filipino Hispanic tradition should be conceived of not only as an aesthetic practice but also as a political tool to be used in the imagination of a new independent nation. Modernist writing in Spanish in the Philippines should move, according to Retana, towards the configuration of filipinidad: the idealisation of the Philippines based on a discourse that served political and national assertion as well as cultural expression.

In my reading, Balmori's poetry does not fully subsume the "spirit of a good patriot" to the "brain of a doubled Parisian," but rather creates its own form of filipinidad by combining the two and having them inflect each other in a process of transculturation. The cultural syncretism of indigenous and foreign motifs, and of literary styles (Hispanic and French modernism), exemplifies Filipino orientalist transculturation. I thus contend that Filipino modernism produces a form of orientalism that is both aesthetic and political; the exoticisation of the Philippines responds not only to an attitude of literary escapism but also to a desire of national affirmation. Balmori, like Darío, is expropriating cultural capital as Casanova (2005) puts it, to create something new. If Darío's modernism was a form of resistance by a Central American author against both European modernism and the Spanish lack of a comparable literary form, Balmori's transcultural orientalism can be considered as the Filipino expropriation of European and Latin American literary modernism in the service of an emergent Filipino nationalism.

The last poem by Balmori I discuss shows another aspect of transcultural orientalism by abandoning self-orientalisation and drawing on Japanese and 
European elements to make visible the Orient as a dramatised representation. Balmori, like some of the Latin American and European travellers mentioned earlier (Loti, Tablada, Gómez Carrillo), found in Japan a source of inspiration for their literature, yet their motivations are different. As noted earlier, in contrast to the writings about Japan produced by French authors, which were designed to stimulate the imagination, Tablada and Gómez Carrillo were driven by a desire to 'truly' understand the Japanese (and other orientals), although, as Clark (2013) notes, they were also heavily influenced by their preconceived images of them and had to negotiate between their expectations and experiences. Balmori's position with regards to the orientalisation of Japan in "La Gueisha" and in the novel Los Pájaros de Fuego is different again. On the one hand, as a writer, he also uses idealised stereotypes (national symbols such as golden temples, geishas, cherry blossoms) to develop a positive image of Japan; on the other hand, like many Filipinos in the period leading up to WWII, he admires the perceived strength and consistency of the Japanese sense of nationhood, which he feels is lacking in the Philippines.

The twenty-ninth poem in Balmori's collection Mi Casa de Nipa (1941), "La Gueisha" presents another example of transcultural orientalism, this time by appropriating the figure of the Japanese performer:

Es de noche, es un salón, y son las once.

Suena un gong como un violón de viejo bronce.

Se descorre la cortina de oro y grana, Y en la escena que simula un nuevo Oriente Se adelanta quedamente, lentamente, La muñeca de esmaltada porcelana.

Se dijera un gran aroma de resedas Toda envuelta entre sus oros y sus sedas Bajo un ritmo musical que sube y sube. ¿Es un ave? ¿Es una flor? No es flor ni es ave, Es la Gueisha langorosa, dulce y suave, Como el paso tembloroso de una nube Va a bailar. Es una danza misteriosa. 
Es un vuelo, es el capullo de una rosa

Que a la luz de los faroles se hace flor.

No se pueden ver sus pies bajo sus galas

Solo mueve sus dos manos blancas alas,

Blancos remos de un ensueño bogador.

Bajo el triunfo de la música que rima

Todo el baile es una grave pantomima.

Y la Gueisha soberana y tornasol.

A los sones de las flautas, sonriente.

Se levanta en espirales de serpiente.

O se dobla como un loto bajo el sol. ${ }^{15}(126-27)$

The poem talks about an evening performance in a theatre. The main character of the "pantomime" is a Geisha, who, through a dance, tells the audience about her (fatal) love story. The Geisha's fiancé-her prometido-has departed in search of "fame" and "fortune" while she, like Penelope, waits for his return. However, when he does not return, the Geisha sees no other ending to her sorrow than to die. The poem concludes with the vanishing of the flute, the sound of the gong and the gold and red curtains being closed again.

In the opening stanza, we are told by the narrator that the stage "simula un nuevo oriente" [simulates a new orient]. The drama, therefore, does not take place in Japan, in the Philippines or in Mexico, but in a simulated or staged orient in which the Geisha performs (or is performed) accompanied by music. The Geisha is compared in her movements to a porcelain doll, a snake and a lotus. In the third stanza, it is announced that she is going to dance "una danza misteriosa" [a mysterious dance] in which she twists like a snake or bends with the flexibility of a lotus in the sun. It is remarkable that both female characters in "Rima Malaya" and in "La Gueisha" are being orientalised by the (presumably) male poetic voice. In the case of Carmencita as an object of love and desire, and in the case of the geisha as an spectacle of visual enjoyment. "The Gueisha" is also a poem about intrigue involving the reader/spectator expressed by the narrator's demands to interpret the geisha's movements in order to find out what her story is: 
¿Qué nos dice en sus solemnes movimientos?

¿Qué nos cuentan sus menudos pasos lentos?

¿Qué oriental historia es esta de la danza,

Que al abrir la media luna de sus ojos

Se dijera traspasada en los abrojos

Como pobre mariposa su esperanza?

¿Es tristeza? ¿Es alegría lo que siente?

¿Qué misterio perfumado del Oriente,

¿Qué divino mago rito religioso

Desenvuelve como en ondas de un aroma

Esta flor, esta mujer, esta paloma,

Con el ritmo de su cuerpo cadensioso? ${ }^{16}$ (127-8)

The rhetorical questions written in the present tense suggest that the narrator perhaps knows the story and is building the reader's expectations while asking him/her to interpret it. The poem explicitly includes the reader by using the first-person pronoun "nos": "¿Qué nos dice en sus solemnes movimientos?” [what is she telling us in her solemn movements?] (my emphasis). It continues: “¿Qué oriental historia es esta de la danza? [...] ¿Es tristeza? ¿Es alegría lo que siente? [...] ¿Qué misterio perfumado del Oriente?” [What oriental story is behind the dance? Is it sadness? Is it happiness what she feels? What fragrant mystery of the Orient?]. In referring to her as a mystery of the Orient, the narrator reveals his own doubts about interpreting her movements and also evokes a familiar orientalist motif, that of the Asian as inscrutable and mysterious, which in the case of (orientalised) women it is also a game of seduction. The mystery, however, is in the end not very enigmatic, as the Geisha is the protagonist of an archetypal narrative (not specific to the Orient, neither to a Geisha) of waiting in vain for the return of one's great love. In this way, the reader of the poem is prompted to reflect on his or her own investment in orientalist motifs.

The elements that Balmori juxtaposes in this simulated orient are oriental and occidental-the gong, the porcelain doll, the snake, the lotus, the Geisha and the mysterious dance versus the double bass, the rose and the Penelope-like story. At the same time, the framing narrative of the poem's 
speaker viewing the performance brings to the fore the artificiality of the oriental pantomime and reveals the ability of the author to braid together the cultural elements that constitute the "new orient" into a scene that does not aspire to be authentically Japanese but only playfully so.

Here, unlike in the other two poems, Balmori's transcultural orientalism does not refer to the history of colonisation affecting the Filipino self. Instead, the poet looks to another orient as a source of inspiration, while also thematising orientalism and playing with the expectations it fosters in the reader. In the end, "La Gueisha" does not orientalise Japan in a hegemonic way, as "Blasón" does with Spain, or show aspects of the Philippines (sampagas, mayas, Kundiman songs) and the West (the white princes and the castle) coming together as a way of achieving national affirmation, as it occurs in "Rima Malaya." Instead, "La Gueisha” is an example of a transcultural orientalism that works through playfully combining elements from Japanese and Western cultures showing a creative and unique literary imagination. Images of the East are animated by Western fantasies and images of the West by Eastern fantasies.

\section{Conclusion}

Drawing on and going beyond Said's idea of orientalism as a form of othering that visualizes the power dynamics of European colonialism and Tinajero's comments on Latin American modes of orientalist literature via travel writing I have described transcultural orientalism as a framework from which to understand elements at play in representations of the Orient in Hispano-Filipino literature. Specifically, I see Filipino orientalism in these three poems by Jesús Balmori as a transcultural mood, as the articulation of a double consciousness (Tagalog and Hispanic) that offers a unexplored vision of the history of colonialism in the Philippines that shows the investment of Balmori in its Hispanic elements, meanwhile neglecting the American influence and looking outwards towards Japan, especially in the poem "La Gueisha”. The theme of Filipino japonism is further developed in his novel Los pájaros de fuego [1945] (2012). 
The three of Balmori's poems I have analysed here incorporate the 'native' and 'the foreign' (whether Spanish, Malay or Japanese), and engage with the received ideologies of East and West in order to imagine a new Philippines, a place where Eastern and Western fantasies meet (at the sea shores, at palace gardens, in tropical forests or in theatre performances). Elements of orientalism are indeed perceptible in Balmori's poems through the the exoticisation of local elements, for example nature (in "Rima Malaya"), the new-born Filipino man (in "Blasón") and the Oriental woman (in "La Gueisha"). The female characters in these poems, Carmencita and La Gueisha are objectivized: they are spoken for and looked at. Spain is also casted as a woman, however, her role as a mother eschews any seductive orientalism, and it is, instead, idealised as a colonial power. Notwithstanding, Balmori does not merely reiterate orientalism to represent a despotic, stagnant and libidinized orient but a place of national affirmation that opens a wider vision of the Philippines.

Unlike Tablada and Carrillo who attempted to 'truly' understand another Orient through travel and travel writing, Balmori's approach to Japanese culture for example does not respond to a necessity of knowing or a desire to establish an intercultural dialogue, but constitutes an act of expropriating its symbols and figures for his own literary experimentation.

Tablada and Gómez Carrillo re-signify European orientalism establishing a transpacific link with China and Japan through travel writing, Balmori does so but statically, through a process of literary transculturation that does not require going to the orient but being in the Philippines and see the Philippines through and in parallel to other cultures. For example drawing an analogous vision of Filipino and Peruvian mestizaje in his own (re)writing of "Blasón”.

In "Orientalism Reconsidered” Said explains that orientalism takes the point of departure of "formerly un- or mis-represented human groups to speak for and represent themselves" in a history that has overwritten them and now they write. He claims that the position of the orientalised is empowered by what he calls an alternative vision of things, a "libertarian optic" that "entails nothing less than the creation of new objects for a new 
kind of knowledge" ("Reconsidered" 91). Looking at Hispano-Filipino literature from a transcultural perspective may be an exercise of seeing through such libertarian optic. Rather than solely promoting liberation from the occidental gaze on the Orient(s), and consequently, writing back at Occident from the Orient, it opens a field of vision in which Filipino literature written in Spanish can offer a global views of the Philippines and its constitutive Others. 


\section{Notes}

1. One of the most complete recent works on Orientalism in Latin American literature is the volume edited by Erik Caymad-Freixas entitled Orientalism and Identity in Latin America: Fashioning the Self and Other from the (Post) Colonial Margin (2013). Another interesting work is Torres-Rodríguez's “Orientalising Mexico: Estudios indostánicos and the Place of India in José Vasconcelos' Raza Cósmica" (2015), which connects with Caymad-Freixas's discussion of the construction of a cultural link between Asia (mostly China and Japan) and Latin America by Latin American intellectuals, including Octavio Paz.

2. For the [Latin American] modernist the act of orientalizing did not mean finding an opposite answer to the ethical, moral and aesthetic principles of European society. Neither did it aim at responding to the European orientalism of the fin-de-siècle or at blindly imitating its literary production. This was emphasized by Aníbal Gonzalez's suggestion that modernists knew exactly what they were doing when, in the same text, they combined references to the Far East with ones to indigenous cultures, while at the same time citing European authors. This, does not mean however that the reason why the members of the movement engaged in a dialogue with the European orientalists was based on an attempt to exclusively antagonize the European vision of that part of the world.

3. I have finished reading Loti's Madame Chrysantheme for the second time and as much as I love the praise of the delightful writer, the frivolity of his judgments, the perfect incomprehension of the true Japanese exasperate me.

4. José Juan Tablada departs tomorrow to Japan. The poet will accomplish his youthful dream... Go artist! Go, you, the chosen one! Study and be fruitful, and may your noble work on touching the most suggestive of plastic arts, because it is profoundly original, may be fertile in our land... When enchanted you behold a snowflake from Fusiyama floating on a golden sea, dream of the distant and peaceful Citlaltepetl.

5. The transmigration of souls, the attributions of domestic divinities, the use of luck charms, the belief by which the dragon eats the sun in its eclipses, monastic rules.

6. [the old Egypt] was not dead. The Muslims and the English might have been able to dominate it but not to transform it. A strong national exhalation would be enough to make all turbans and colonial helmets disappear.

7. One of the arguments put forward by the Indian scholar Partha Chatterjee (1993) on postcolonial nationalism is that colonial administrations may have dominated the 'material realm,' but never fully penetrated the 'spiritual realm'; this sentiment is echoed in the judge's insistence that "the old Egypt" has survived. 
8. Rubén Darío's poem “La Sonatina," included in Prosas Profanas (1895), is one of the best examples of modernism. Balmori wrote a short play entitled La Princesa está Triste (1919), taking the second verse from Darío’s “Sonatina” as a departure point.

9. I am an Indo-Hispanic poet. In my Christian chest / My heart is a vase where the blood of Legazpi, the Hispanic captain/mixes with the Tagalog blood of the daughter of the Rahá / With my heel sunken in the foam of the waves, / I awaited on the sea for the Spanish galleon / And Spain, when she found me, kissed the golden feathers / That trembled on my forehead like rays of sun / She was beautiful, she was good, she was loving / I laid my spears, my thorns and my flowers at her feet / I gave her my wild oriental heart / Since then I carry her on my naked chest/Serving me as glorious iron shield / With its divine language and immortal blood.

10. Filipinos identify themselves as belonging to the Malay peoples, which also populated Indonesia and Malaysia; they often use the short form 'indo.'

11. In the pre-Hispanic Philippines, most of the chieftains were called Rajah, the Arab term for 'king.' Islam was the most widespread religion and its terminology was used for many elements of government. See Isaac Donoso's "El islam en las letras Filipinas" (2007).

12. It was the tropical night of the orient / Illuminated by a somnolent moon / A thousand lightning bolts were shining in the sky / thunder resounded violently / Mute was the garden, the birds were asleep / In their nests of leaves and feathers / And quietly the wind whispered / Twirling around the lilies and the roses. / With hesitant feet and hands / I climbed the fence of golden threads / The zephyr brought me in his wings / The tremulous murmur of her sighs.

13. Say yes, I will go but with you / Back to the oriental forest of green branches / Where the mayas sing our love / Where a bed of sampagas awaits you.][...] Oh! Come, come with me my beloved Carmencita, / If you do not know how to love, I'll be there at your feet/ Singing the waltz of the Kundimans / I will crown your forehead with champakas.

14. To Jesús Balmori, one of the youngest poets whom I would add to my list of most promising; however, the attack of fulminant modernism that he suffers from may not let him live long. Balmori has never left his country, but mentally he lives in Paris, in the mysterious, tragically bohemian Paris of the Quartier Latin... Balmori wants, above all things, to be a sick Parisian and thus he has become sick by virtue of pure spirituality, because he cannot conceive the idea of being a poet without dying of sadness, of Parisian sadness. [...] I have censured Balmori because he has the soul of a poet, and yet, he is throwing all his talent away as a consequence of having created himself in a false environment, one that is anti-Filipino, and a fair critique must demand payment for such a profound aberration. In Balmori fight the spirit of a good patriot and the brain 
of a doubled Parisian; since he puts his will at the service of his brain, many of his compositions are... a true pain.

15. The night has fallen, inside the room, the clock strikes eleven / The sound the gong is heard resonating like a double bass old bronze / The gold and red curtain are drawn / And on the scene that simulates a new Orient / Comes forward quietly and slowly/ The doll of varnished porcelain.

She smells like the great aroma of mignonettes / All wrapped in gold and silk / The music rises in crescendo/ Is it a bird? It is a flower? It is not a flower, not a bird, / It is the geisha, languid, sweet, soft, / Like the flickering walk of a cloud.

She is going to dance. It is a mysterious dance. / She can fly, she is like the rose bud / That blooms when illuminated by some lantern / Her feet cannot be seen under her clothes / She only moves her hands like white wings / like the white paddles of a sailing dream.

Under the triumph of rhyming music, / The whole dance is a serious pantomime / And the Geisha, sovereign sunflower / Smiling at the sounds of flutes / Rises like spirals of a snake / Or bends her body like a lotus in the sun.

16. What does she tell us in her solemn movements? / What do her slow steps tell us? / What oriental story is there in this dance? / When she opens the crescent moon of her eyes / her hope was pierced in the thistles/ like a little butterfly/

Is it sadness? Is joy what she feels? / What scented mystery of the East / What divine magician, religious rite / Develops in fragrant waves / This flower, this woman, this dove, / With the permanent rhythm of her body? 


\section{Works Cited}

Balmori, J. Los Pájaros de Fuego, Una Novela Filipina de la Guerra. Edited by Isaac Donoso. Instituto Cervantes, 2010. Mi Casa de Nipa. Ateneo de Manila University Press, 1928.

Camayd-Freixas, Erik. Ed. Orientalism and Identity in Latin America: Fashioning Self and Other from the (Post)colonial Margin. The University of Arizona Press, 2013.

Casanova, Pascale. "Literature as a World.” New Left Review 31, 2005, pp. 71-90.

Chatterjee, Partha. Nationalist Thought and the Colonial World: A Derivative Discourse. University of Minnesota Press, 1993.

Chocano, José S, and Francisco Bendezú. Las Mejores Poesías De Chocano. Patronato del Libro Peruano, 1956.

Clark, Zoila. "Enrique Gómez Carrillo’s Japan and Latin American (Periphera) Orientalism” Orientalism and Identity in Latin America: Fashioning Self and Other from the (post)colonial Margin. Edited by Erik Camayd-Freixas. The University of Arizona Press, 2013.

Donoso Isaac. Introduction to Pájaros de Fuego, Una Novela Filipina de la Guerra by Jesús Balmori. Instituto Cervantes, 2010.

Donoso, Jiménez I. “El Islam En Las Letras Filipinas.” Orientalismo: Árabes Y Judíos En La Literatura Hispánica, 2007.

Gómez Carrillo, Enrique. De Marsella a Tokio: sensaciones de Egipto, la India, la China y el Japón. Garnier Hermanos, 1906.

Park, Paula C. "La difusión global de la literatura filipina en español por una ruta transversal” Iberoromania, vol. 87, 2018, pp. 36-49.

Pratt, Mary L. Imperial Eyes: Travel Writing and Transculturation. Routledge, 2010.

Said, Edward W. Orientalism. Routledge, 1979.

___. "Orientalism Reconsidered. Cultural Critique, 1 (Autumn, 1985): 89-107.

Tablada, José Juan. Obras completas. 5 Vols. Edited by Guillermo Sheridan. UNAM, 1991-94.

Tinajero, Araceli. Orientalismo en el Modernismo Hispanoamericano. Purdue University Press, 2004.

Torres-Pou Joan. Asia en la España del siglo XIX. Literatos, viajeros, intelectuales y diplomáticos ante Oriente. Ámsterdam-New York, 2013.

Valera, Juan, and Leonardo Romero. Morsamor. Plaza \& Janés, 1984. 